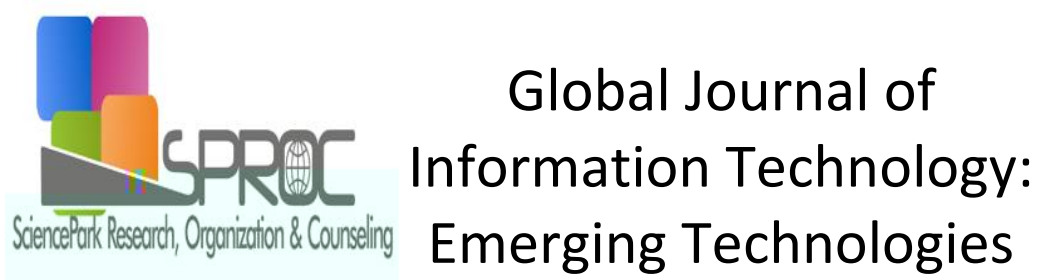

Volume 6, Issue 3, (2016) 166-173

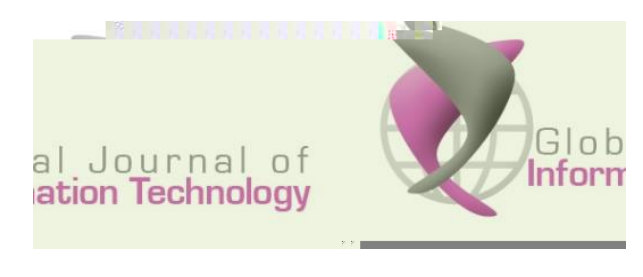

$\underline{\text { www.giit.eu }}$

\title{
Challenges of Facebook integration in high education classrooms, case study Republic of Macedonia
}

\author{
Mentor Hamiti*, Faculty of Contemporary Sciences and Technologies, South East European University, \\ Ilindenska 335, 1200 Tetovo, Macedonia
}

Batije Shefketi, Faculty of Contemporary Sciences and Technologies, South East European University, 335, 1200, Ilindenska Tetovo, Macedonia

\section{Suggested Citation:}

Shefketi, B. \& Hamiti, M. (2016). Challenges of Facebook Integration in High Education Classrooms, Case Study Republic of Macedonia.

(3), 166-

173

Received May 17, 2016; revised August 24, 2016; accepted September 5, 2016.

Selection and peer review under responsibility of Prof. Dr. Dogan Ibrahim, Near East University, Cyprus.

(C)2016 SciencePark Research, Organization \& Counseling. All rights reserved.

\begin{abstract}
Currently, the Internet has become a part of the everyday life of human beings. The way of communication between people has changed and social networks are dominating in the lives of everyone. One of the most used social networks is Facebook, but besides that it is used for communication and entertainment, Facebook can also be used for learning. Therefore, the main issue of this paper is the use of Facebook for educational approaches by students and teachers. Case studies are the challenges of integration of Facebook in High Education in the municipality of Kumanovo in the Republic of Macedonia in 2016. Special emphasis is devoted in usage of Facebook in schools as the main questions were whether students use Facebook to ask for help for assignments or any material, and do teachers use Facebook to post assignments and to communicate with students. To understand this, there are conducted two questionnaires, one to students and one to teachers and interviews with school principals, and finally responses of people who participated have been analysed. The result is that by joining Facebook in education, students are more motivated to learn, Facebook helps students to learn by sharing knowledge with each other and by using Facebook at school, teachers will find it easier to inform students.
\end{abstract}

Keywords: social network, facebook, communication, high education, classroom.

\footnotetext{
*ADDRESS FOR CORRESPONDENCE: Mentor Hamiti, Faculty of Contemporary Sciences and Technologies, South East European University, Ilindenska 335, 1200 Tetovo, Macedonia. E-mail address: $\underline{\text { m.hamiti@seeu.edu.mk }}$
} 


\section{Introduction}

The Internet has changed the world. Open access to the Internet has revolutionized the way individuals communicate and collaborate, entrepreneurs and corporations conduct business, and governments and citizens interact. At the same time, the Internet has created an open revolutionary model for its development and governance including all stakeholders. The internet development was supported so critically in creating an open process. Fundamentally, the Internet is a "network of networks", whose protocols are designed to allow networks to interact. At first, these networks represented various academic, government and research communities, whose members needed to work together to develop common standards and manage shared resources (Internet Society Global Internet Report, 2014) According to Computer Hope (2013) as a social website, alternatively referred to as a virtual community or profile site, a social network is a website that brings people together to talk, share ideas and interests, or make new friends. This type of collaboration and sharing is known as social media. Unlike traditional media that is typically created by no more than ten people, social media sites' content is created by hundreds or even millions of different people (Computer Hope, 2013).

According to Lenhart (2015) Facebook is the most popular and frequently used social media platform among teens, half of teens use Instagram, and nearly as many use Snapchat.

Figure 1. Percentage of teenagers who use social networks $\%$ of all teens 13 to 17 who use ...

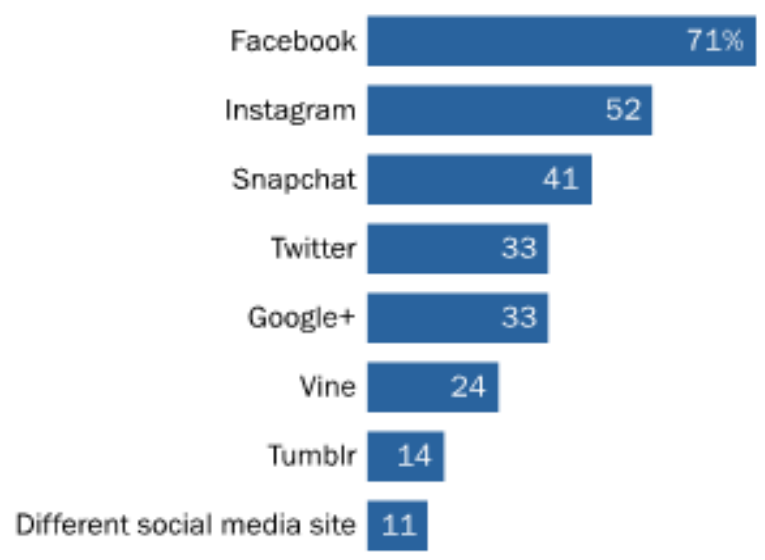

In the recent years the integration of technology and computers in teaching and learning is increasingly becoming an integral part of the educational system. This trend has begun to expand in primary and secondary education, but is currently more pronounced at the university level. This does not mean that teaching and learning as a social process in general, tends to be replaced effectively by technology. But, on the contrary, technology can serve the educational process in different ways. Technology is ubiquitous touching almost every part of our lives, our communities, our homes. However, most schools are lagging far behind when it comes to integrating technology into classroom learning.

\section{Facebook in teaching}

In the field of education, technology does not have a secondary role in the sole process of the transfer of knowledge especially because technology is becoming more and more integrated into the lives of students of all ages and groups. The special part of this technology is the use of Facebook as an educational tool. Being originally designed for college students in the United States in 2004, Facebook was created as a social networking website. Facebook later expanded to various areas of education. Facebook allows any user to create a profile, update it with personal information such as home address, mobile phone number, interesting religious views and also allows people to form groups and posting photos (Ngoyi, Siuluta, Muwamba, Banda, Hatilimab \& Ngoyi, 2015). A Facebook 
is also used as an educational tool due to the fact that it is independent of time and place, so students and lecturers can send information even when they are not in the classroom or lecture amphitheater.

\section{Facebook as a technological learning tool}

A story about the Facebook in the classroom: "In my British Literary History course last winter semester, my professor created a class Facebook group which we all joined. We'd finish our reading for class and then get online and write a paragraph about what we'd read, focusing our comments on the specific course aims that my professor had created for the class. We would then go to class where my professor would note the ways in which we'd covered the material well and he'd teach anything we missed as well as anything else he wanted us to know. This way of conducting class was effective because:

- We were socially motivated to complete the reading and contribute to the online discussion.

- We didn't spend class time going over that which we already understood.

- We were able to benefit from insights from peers who generally don't participate in class discussion.

- We all learned to focus the vast amount of reading required for such a course to the specific course aims of our professor.

- Through contributions from our classmates, we understood how each distinct text related to the others and to the class focus, and so on.

We shouldn't discount Facebook when it has proven to be a worthwhile classroom tool. I should also note that a class Facebook group doesn't require the professor or students to "friend" each other to participate." So by Kelly Walsh Facebook is mainly used to help a discussion group, which can certainly be done through an LMS like Blackboard or Moodle or other different tools, but the good thing about Facebook is that many students ar-121(o)5(t( )3(Fahdyt )-25far)12(m)-4(il)3i(ar)50( )-23(an)4(d)3( )2 


\section{The best practices for educators on Facebook by Junco}

Junco states that there are tips on how to effectively use Facebook in the classroom.

- Use Facebook With a Focus - "Instead of telling your students, 'Hey, we are going to use Facebook for this course,"' Junco emphasizes that "it is important to frame Facebook use in a way that will make sense. For instance, you could say 'we are going to use a Facebook group in order to interact with each other, discuss course topics, and share links of interest".

- Friend With Caution - Regardless of whether the legislation was justified, there's a reason that Missouri banned social media friendships between teachers and students. In many cases it is not any more appropriate for teachers and students to hang out on the Internet after school than it is in reality. Not to mention that both parties can feel uncomfortable when social networks make their lives outside of the classroom accessible in a classroom context.

- Use a Facebook Group - In addition to using Facebook groups in his own classes, Junco has conducted research on how they can be incorporated into learning most effectively.

- Use a Facebook Page - Because Facebook pages are open to the public and anybody can subscribe to their content, they are typically used differently than Facebook groups in educational settings. They often become interactive resources rather than a setting for intimate discussion. (Kessler, 2011)

\section{Some entertainment ways to use Facebook on your lesson plans and teaching}

Who among us did not have to do a biography report on a famous author or historical figure? Think about how much more fun that project would have been if you could have created a Facebook fan page or profile for that person instead. Teachers of all subjects can use this idea to help their students learn more about significant figures in a certain field. Students can create complete pages for their figures, including biographical information, "Likes", photos, and even status updates to show they have a thorough understanding of the material.

Classes that study social studies, media, film, religion, politics, and more can make good use of the social connections on Facebook to conduct surveys and opinion polls for research. Want to study family traditions? Conduct a poll amongst friends. Want to discuss cultural beliefs? Host a survey on the network. The Facebook Questions feature allows you to do this. Of course, some surveys or polls may be limited based on how many people students are able to reach through the network.

A Facebook group is a great way to leverage the power and popularity of this application to distribute learning content and create a central place for communication for a course or class.

Tap into information about specific topics

Chances are there are some groups and pages out there that are focused on issues relevant to your course. Type the name of your academic subject in Facebook's search window and you will automatically get a list of related content. For example, type "Algebra" and you will get Wikipedia's definition, but you will also get a handful of pages with related focuses such as books, 'Interest', Groups, and more. 
In many ways, Facebook is like a giant phone game. People sometimes hear about news, events, and products on Facebook first. Of course, rumors have a way of going viral before misinformation is corrected, and there is a challenge here to be able to differentiate legitimate information from assumptions, gossip, hype, etc. There is an opportunity to leverage this in a critical thinking context. For example, students can search other sources to validate information they come across in Facebook. The way news spreads on Facebook also offers a unique opportunity for study by students of journalism or mass media. Facebook offers many opportunities for use in the classroom. However, its applications may not always be obvious, and some creative thinking is required. (Walsh, 2012)

\section{Results}

In the context of this topic a research about how many students and teachers use Facebook for educational issues was conducted. According to the quantitative method, there was realized a survey including two questionnaires, one receiving responses from students and the other from teachers in the secondary schools in the municipality of Kumanovo. On the other hand, based on the qualitative method, was carried out an interview attended by directors of secondary schools in the municipality of Kumanovo, Albanian language classes.

In February 2016, in the research organized for students, have participated 368 students from a total of 2740 secondary schoolers in the municipality of Kumanovo classes in Albanian language. This number includes the students from economic high school "Pero Nakov", technical high school "Nace Bugjoni" and secondary school "Sami Frasheri".

Figure 2. The number of students participated in research

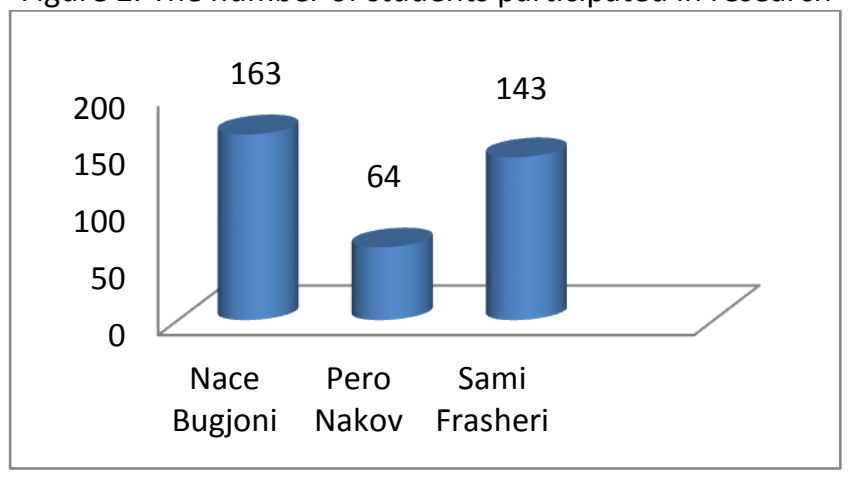

Despite the fact that $60.6 \%$ of students use Facebook, 50.5\% use Facebook for learning, $23.4 \%$ sometimes and $26.1 \%$ never use Facebook for educational issues

Figure 3. Percentage of how many students use Facebook to learn

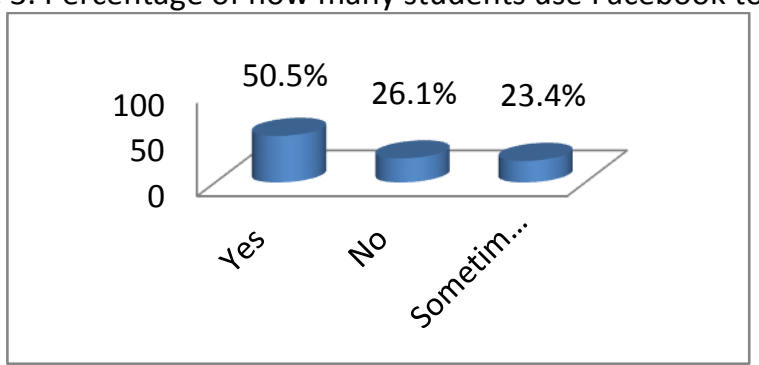


As discussed above, through Facebook students can seek help for assignments that they do not understand, but in the questionnaire they said that only $40.8 \%$ require assistance for assignments on Facebook, $21.3 \%$ sometimes and $36.1 \%$ were expressed "no", which means that they do not use Facebook to ask for help for assignments.

The use of Facebook in education can have positive and negative effect. $57.1 \%$ of students think that Facebook usage has a positive effect because:

and $42.9 \%$ think it has a negative effect because:

Using Facebook by teachers in class for educational issues can have an impact on students by creating fun time while giving away traditional methods. Whether students feel more motivated when Facebook is being used by their teachers, can be found out through students' responses, among which $67.1 \%$ said they feel motivated and $32.9 \%$ feel demotivated.

Figure 4. Percentage of students motivated and demotivated

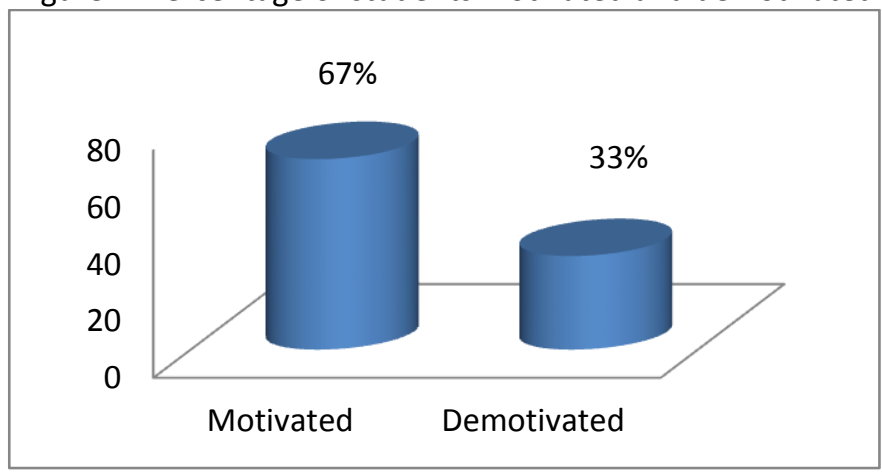

By using Facebook, teachers can also post assignments for students in any group, which is a good idea if the teacher has not had the opportunity to show assignments in class, but only $39.4 \%$ of students responded that teachers post assignments, sometimes $19.6 \%$ and $41 \%$ never. By integrating Facebook in education students can achieve better results. The majority of students, $57.3 \%$, stated that the integration of Facebook in education could help achieve better results and $42.7 \%$ said no.

Figure 5. Percentage, if is achieved good results with the Facebook integration

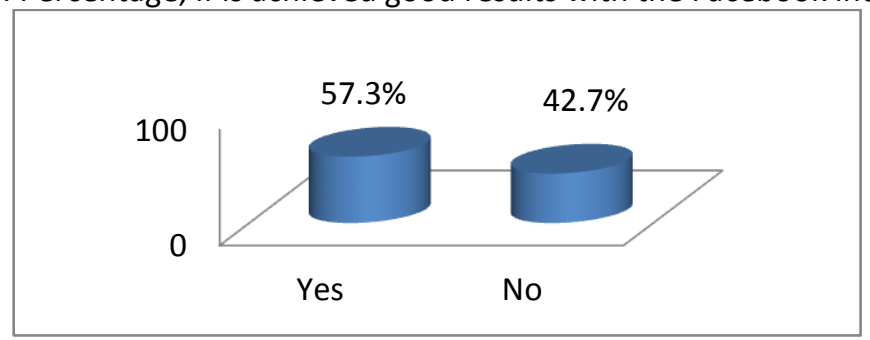


Shefketi, B. \& Hamiti, M. (2016). Challenges of Facebook Integration in High Education Classrooms, Case Study Republic of Macedonia. (3), 166-173

In February 2016, in the research organized for teachers, have participated 40 teachers from a total of 216 secondary school teachers. Here are involved economic high school "Pero Nakov", 
But whether they will use Facebook in the future for teaching, only $17.5 \%$ said yes, $67.5 \%$ probably and $15 \%$ will not use.

Part of this interview have been three directors of secondary schools in the municipality of Kumanovo, classes in Albanian language, director of high school "Sami Frasheri", Economic School "Pero Nakov" and the director of technical secondary school "Nace Bugjoni". According to school principals, who had similar thoughts, technology integration in their schools was not at an appropriate level. Inclusion of Facebook in teaching according to school principals was not a good idea because they thought that Facebook cannot help students to learn, because it may distract students, even if they use it for educational purposes. Instead of Facebook, school principals thought that it would be better to create a website where they can communicate and be informed about educational issues and in order to improve the quality of students, they said that it is definitely necessary to do a proper involvement of technology in the teaching process.

\section{Bibliography}

Computer Hope (2013). Retrieved September 30, 2015, from Social network: http://www.computerhope.com/jargon/s/socinetw.html

Hartstein, D. (2011). How Schools Can Use Facebook to Build an Online Community. Retrieved January 17, 2016, from http://mashable.com/2011/04/26/facebook-for-schools/\#20SSZOlfKGqS

Kende, M. (2014). Internet Society Global Internet Report 2014. www. internetsociety. org/sites/default/files/Global_Internet Report 2014 0. Pdf (accessed December 15, 2015).

Lenhart, A. ( 2015). Teens, Social Media \& Technology Overview 2015. Retrieved March 12, 2016, from http://www.pewinternet.org/2015/04/09/teens-social-media-technology-2015/

Ngoyi, L., Siuluta, M. N., Muwamba, J., Banda, D., Hatilima, J., \& Ngoyi, A. (2015). Use of facebook as an educational tool. Retrieved January 16, 2016 from http://www.ijrdo.org/International-Journal-ofResearch-\&-Development-Organisation-pdf/Applied\%20Science/July-2015/Jas-2.pdf

Walsh, K. (2010). Facebook as an Instructional Technology Tool. Retrieved January 22, 2016, from http://www.emergingedtech.com/2010/08/facebook-as-an-instructional-technology-tool/

Walsh, K. (2012). 5 Fun Ways to Use Facebook in Your Lesson Plans and Teaching. Retrieved January 21, 2016, from http://www.emergingedtech.com/2012/08/5-fun-ways-to-use-facebook-in-your-lesson-plans-andteaching/ 